Research, part of a Special Feature on Realizing Water Transitions: The Role of Policy Entrepreneurs in Water Policy Change

\title{
Individuals Matter: Exploring Strategies of Individuals to Change the Water Policy for the Tisza River in Hungary
}

\author{
Saskia E. Werners, Piotr Matczak, and Zsuzsanna Flachner
}

\begin{abstract}
This paper offers a novel interpretation of the introduction of floodplain rehabilitation and rural development into the water policy for the Tisza River in Hungary. It looks at the role of individuals and the strategies that they used to bring about water policy change. Five strategies are explored: developing new ideas, building coalitions to sell ideas, using windows of opportunity, playing multiple venues and orchestrating networks. Our discussion on the importance of each strategy and the individuals behind it is based on interviews, group discussions and a literature review. The international and political attention sparked by a series of floods, dike failure and a major cyanide spill, which preceded national elections, opened a window of opportunity for launching ideas. A new regional coalition successfully introduced floodplain rehabilitation into the water policy arena. Our analysis emphasizes the importance of a responsible civil servant who recognizes a new policy idea at an abstract level and a credible regional coalition that advocates the new idea regionally.
\end{abstract}

Key Words: coalition; individual actor; Hungary; Tisza River; transition; water policy change

The whole world had already been created when the Tisza was standing alone before the Lord's throne. Then Jesus took a golden plough, harnessed a donkey to it and told the Tisza to follow. Thus he set the plough against the soil and ploughed the bed for the river, which followed faithfully everywhere. However thistles were scattered all around. The donkey, which was feeling hungry reached after one and then another, leaving a straight path. This is why the Tisza is so unpredictable, so winding and meandering.

- Hungarian folk tale

\section{INTRODUCTION}

This paper analyzes the early 21 st-century transition in water policy for the Tisza River in northeastern Hungary. In the spring of 2003, the Hungarian government issued a decree that marked a substantial shift in water management. The new water policy for the Tisza River recognized rural development and nature conservation as important objectives alongside flood protection. Floodplain rehabilitation and land-use change were introduced as water management measures to replace or complement the prevailing engineering approaches, which primarily favored flood levee construction. From an external perspective, this change in policy was surprising given that for 150-years water management had been dominated by river normalization, flood levees and drainage of floodplains, mainly serving the interests of largescale agriculture. The development and implementation of the new water policy, called the New Vásárhelyi Plan, between 1998 and 2006 is the main object of investigation of this paper. The changes in water policy for the Tisza have been previously analyzed for example, they have been discussed from a governance perspective (Werners et al. 2009). This paper takes a new approach by assessing the role of individual actors and the strategies that they used in bringing about policy change.

We build on our research in a series of Hungarian and international research projects. We collected data in three ways: through twenty interviews with actors from national and regional organizations 
(ministries, water authorities, planners, academic institutions, non-governmental organizations (NGOs), municipalities, and farmers); through a series of group discussions with local and national stakeholders; and by an analysis of policy and project planning documents and background studies.

We begin with an account of why we call the water policy changes a transition. Next, we describe the changes from the perspective of five strategies (Huitema and Meijerink 2009; Huitema and Meijerink 2010):

1. Developing new ideas (cf. Hajer 1995, Baumgartner and Jones 2002, van der Brugge et al. 2005);

2. Building coalitions for selling ideas (cf. Sabatier 1988, Folke et al. 2005, Olsson et al. 2006);

3. Recognizing and exploiting windows of opportunity (cf. Kingdon 1995);

4. Using multiple venues (cf. Baumgartner and Jones 2002); and

5. Orchestrating networks (cf. Folke et al. 2005, Caniëls and Romijn 2008).

We then discuss the importance of each strategy and provide a review of the individuals behind it. Our analysis shows the importance of 1) responsible civil servants who recognize a new policy idea at a conceptual level and 2) a credible regional coalition that advocates the policy concept. The international attention and domestic political focus following the 2000 cyanide disaster on the Tisza River, the 2001 floods, and the 2002 national elections provided a window of opportunity for the adoption of the new water policy. Ambiguity about the practical application of new policy concepts and the responsibilities of different actors initially facilitated consensus on the new water policy but has since hampered its implementation.

\section{BACKGROUND: TISZA RIVER BASIN AND THE TRANSITION IN WATER POLICY}

A short historical overview of water management in the Tisza River Basin helps provide the context for and arguments why the changes introduced into
Tisza water policy may be called a transition in water policy. The Tisza River is the largest tributary of the Danube, receiving water from the Carpathian Mountains in Romania, Slovakia, and Ukraine. The Tisza River Basin holds almost fifty percent of Hungarian territory. Until the 18th century, river management was mainly organized around the operation of a system of small streams and channels regulating the water flow between the main riverbed and the floodplain (Balogh 2002). The inundation frequency determined land use. Mosaic floodplain production systems combined plough land, forest, floodplain orchards, meadows for cattle grazing, and fisheries (Andrásfalvy 1973). Since the 1750s, the Tisza River has been heavily modified. To cater to large-scale mono-agriculture, mills and river transport, the river was canalized and straightened, and the floodplains were drained. The 19th century First Vásárhelyi Plan set out the main changes. Dike building, river regulation, and floodplain drainage decreased the total naturally flooded area by eightyfour percent (see Figure 1). These changes ended the traditional water management system and the related production systems on which the communities along the river had relied (Bellon 2004).

The recurrence and high visibility of floods caused resources to be funneled into an extensive flood defense system (Vári 2001). Over a period of 150 years, deforestation and river normalization made the river flow more extreme and, together with population growth in the low-lying reclaimed floodplain, added to flood risks (Fejér 2004). In addition to flooding, water management was though to contribute to problems such as drought, water stagnation, soil salinisation, and the degradation of peat lands and wetlands (Vámosi 2002). The communist era following the Second World War advanced large-scale tillage and agricultural production systems that required floodplain drainage. Privatization at the beginning of the $1990 \mathrm{~s}$ led to a drop in the operation and maintenance of the large irrigation systems and a decrease in agricultural output. At present, a high unemployment rate, aging, and migration challenge the region socio-economically (Sendzimir et al. 2004, Linnerooth-Bayer et al. 2006). On a more positive note, the region has great potential for recreation and nature conservation (Vári et al. 2003).

The annual floods that returned in 1998 after twenty years of drought were a driving force behind the development of a new water policy for the Tisza 
Fig. 1. Tisza River Basin: river regulation has reduced river length by one third and the floodplain area by 80 per cent.

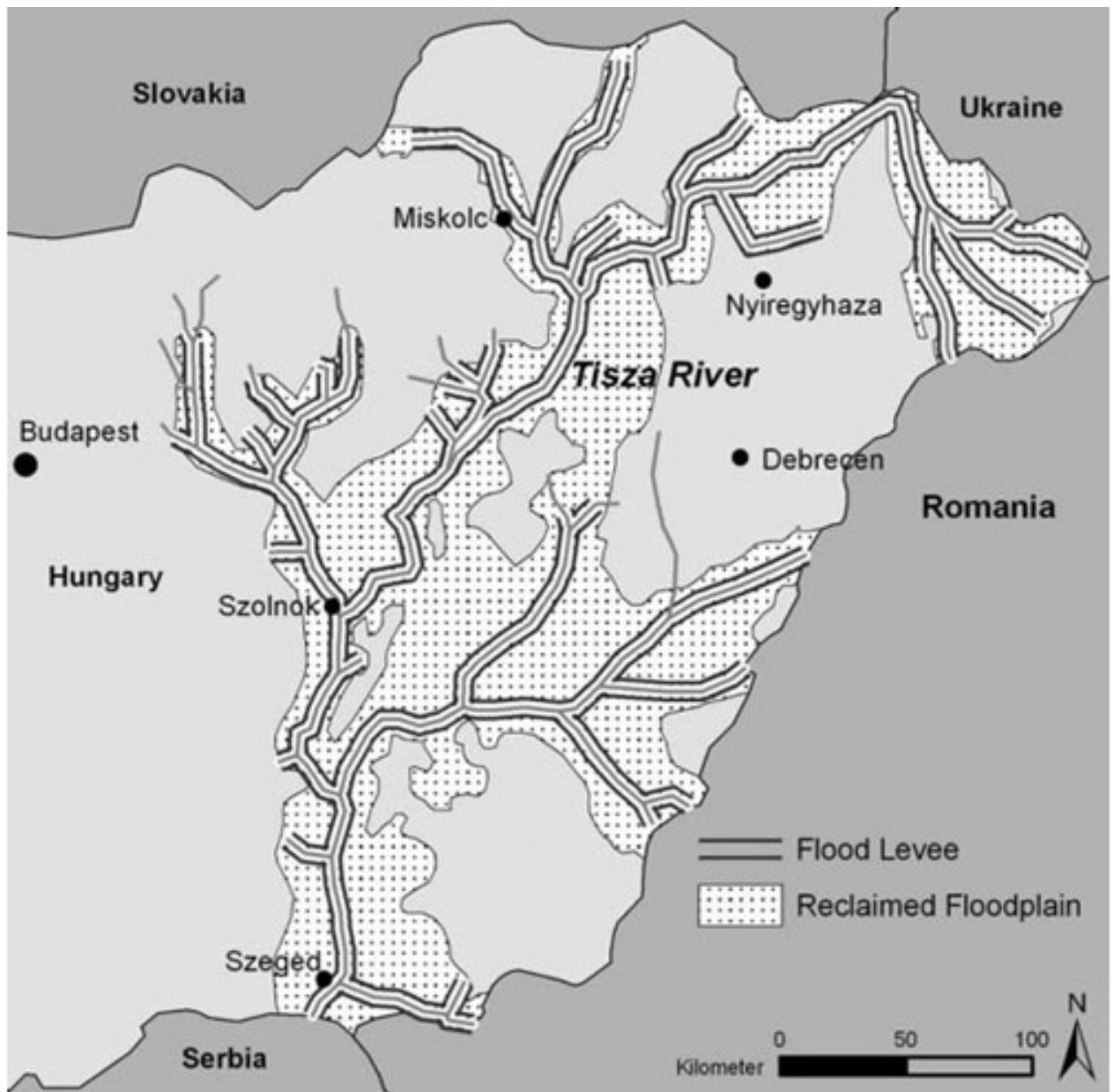

River: the New Vásárhelyi Plan (in Hungarian: Vásárhelyi-Terv Továbbfejlesztése (VTT)). Interviewees distinguished three stages in the development and implementation of the VTT:

1. 1999 - 2001: The water authority and the Ministry of Transport, Communication and Water announced the first policy plan. The goal of the first policy plan was flood protection with nature conservation considered where appropriate. Single-purpose flood retention reservoirs were the main innovation. The plan was mostly the work of the water authorities. National NGOs, such as WWFHungary, were invited to comment. Local
NGOs protested against the plan, especially the new coalition Bokartisz.

2. 2002 - 2003: During this period, there was intensive collaboration between government bodies, regional NGOs, and research institutes. National government involvement was broadened and organized through an inter-ministerial committee chaired by the Ministry of Environment and Water (established after the 2002 reorganization of the Ministry of Transport, Communication and Water) and involving the Ministry of Agriculture and Rural Development, the Regional Development Agency, and other 
ministries (for example, social and labor). Two government decrees were passed. Government Decree 1022/2003 of February 2003 acknowledged floodplain revitalization, nature conservation, and rural development as objectives next to flood protection. It ordered the development of an implementation plan for the first six retention reservoirs, including rural development and floodplain rehabilitation at local stakeholders' request. Government Act LXVII of 2004 endorsed the implementation plan.

3. 2004 - Present: This period represents the implementation of the new policy. The approval of project sites has been delayed. The implementation focuses on building emergency retention reservoirs. The associated rural development lags behind.

Why do we call the development and implementation of the new water policy a transition? Huitema and Meijerink (2009; 2010) postulate that a transition in water policy should become visible in a reorientation of the policy substance or the governance paradigm. The water policy endorsed in 2003 explicitly recognizes rural development and nature conservation as important objectives alongside flood protection. Floodplain rehabilitation and land-use change were introduced to replace or complement flood levees that had been the preferred solution in water management for 150 years (Figure 2). The national planning agency VÁTI facilitated the intense collaboration of a large number of regional and national actors during the preparation of the implementation plan. This collaboration broke the hegemony of the water authority. Regional interests were represented by regional organizations such as the new Bokartisz coalition, founded in 2001 by the councils of twelve municipalities, three non-profit organizations (EMisszió, the Hungarian Environmental Economics Centre and Palocsa Association) and individual scientists (http://makk.zpok.hu/en/node/118). An inter-ministerial committee made major decisions in consultation with regional and civic organizations. At the National Meeting of Environmental and Nature Conservationist Organizations in 2003, the environmental NGO E-Misszió was elected for full membership in the inter-ministerial committee, which allowed E-Misszió to make proposals, vote and veto. Actors involved in the development and/or implementation of the new water policy reported a "paradigm shift" or "new philosophy". The government brochure for the new water policy also captured this shift in its text and new logo (Figure 2c). The brochure also introduced examples of the rural development and nature conservation component of the policy (VITUKI 2004):

The government has adopted on the 15 of October, 2003 a decision on the most ambitious rural development program of past decades [...] The program reflects a new government philosophy, in that it takes as far as possible into consideration the interests of environmental protection and nature conservation. [...] The complex project, the basic aim of which is to raise the living standards of the people in the Tisza Region, whilst ensuring a higher level offlood safety, would be accompanied by a number of important infrastructural developments. These include land drainage and sewerage, afforestation, construction of cycling lanes, as well as environment management schemes, like the creation of a mosaic landscape pattern by water routing, streamlet rehabilitation, and conveying the water down the full length of the flood bed.

The substance of water policy and the process by which it was designed mark a transition in accordance with the definition of Huitema and Meijerink $(2009 ; 2010)$. We therefore chose the development of the Tisza water policy as the subject of this paper.

\section{RESULTS: EXPLORING STRATEGIES OF INDIVIDUALS}

This section explores the role of individuals in the development and implementation of the new Vásárhelyi water policy (VTT) from the perspective of the five strategies set forth in the introduction of this paper. 
Fig. 2. a) Tisza River at Tiszadada; b) Oxbow lake: traditional water management used oxbows and creeks for water regulation. This inspired the new water management plan; c) Logo and motto for new Vásárhelyi water policy in government brochure (VITUKI 2004); and d) Bicycle lane on retention reservoir dike for rural development (Photos: Werners, 2007).

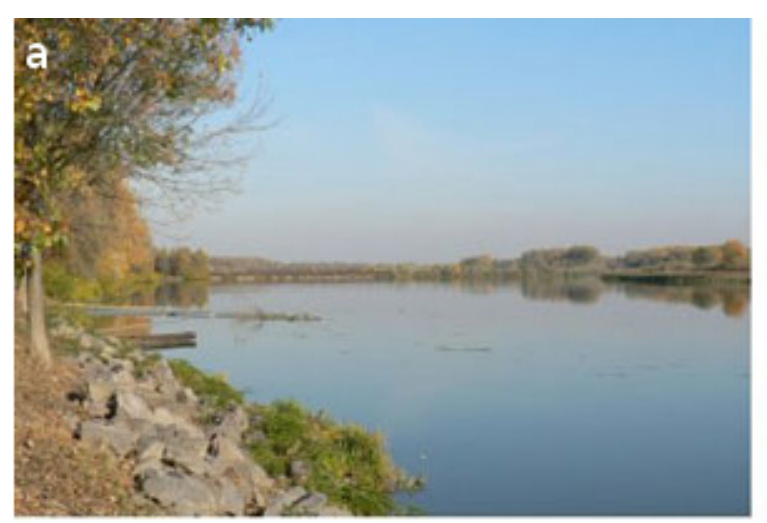

C.

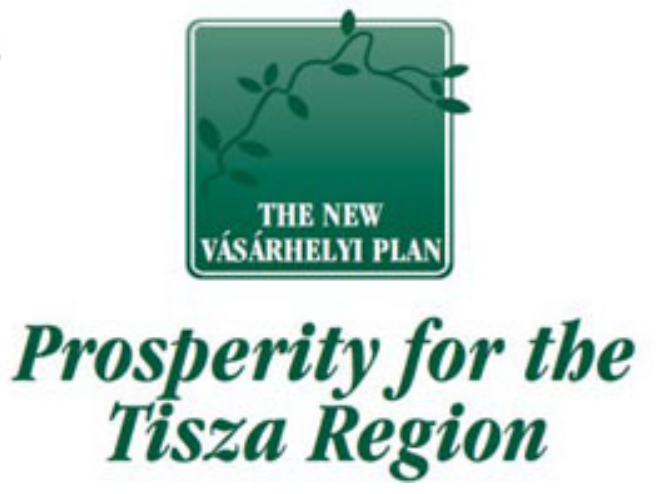

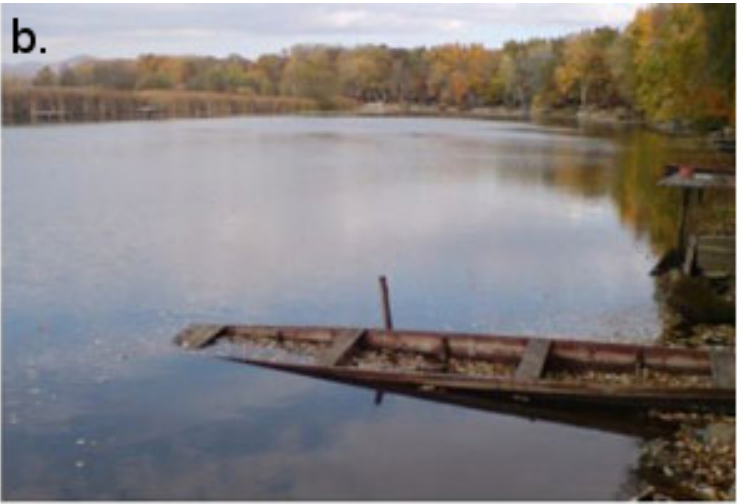

d.

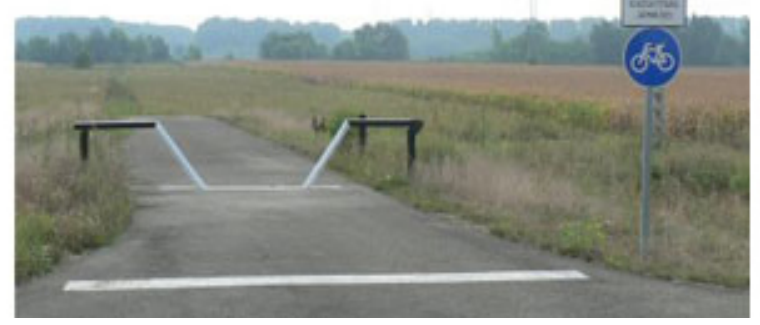

\section{Develop new ideas}

In this section, we investigate the origin of the idea of floodplain rehabilitation, rural development, and nature conservation as introduced into Tisza water policy in 2003. We asked different parties about the origin of this idea and whether one person or group of people could be identified as its source. Members from the Bokartisz coalition point to their own organization and specifically to its leader, Géza Molnár, as the key individual behind the idea of floodplain rehabilitation in the Tisza Region. They claim that their work initiated discussion of the idea within the region and brought the idea to the national level. Since the 1980s, Géza Molnár has studied the floodplain management system in the Tisza valley combining field experiments and document analysis (Andrásfalvy 1973, Bellon 1991). Together with a small group of farmers and landowners, he restored and experimented with traditional water steering systems on a small scale at various locations along the Tisza. Based on these two decades of individual experiments and theoretical studies, the founders of the Bokartisz coalition developed their concept of integrated floodplain management and floodplain rehabilitation with the aim of re-creating a mosaic landscape structure and recurring shallow flooding for sustainable rural development. Coalition members began advocating their concept under the name "Last Straw" in 2001 (Botos et al. 2002). It is important to stress that Bokartisz did not present floodplain rehabilitation as something new but rather referred back to floodplain utilization before river regulation. Their concepts derived from the shallow flooding, mosaic land-use, and community management of small-scale water infrastructure that was common in the Tisza region in the period between 1500 and 1700 . 
We distinguish between the concept of floodplain rehabilitation that Bokartisz members advocated and the more detailed implementation plans for certain locations along the Tisza, particularly the Bodrogköz area. Working both on the more abstract concept and its practical implementation at particular locations, Bokartisz members discussed the feasibility of the concept with local mayors, farmers, national park authorities, and NGOs and demonstrated its application. In the words of a representative of the Hungarian Environmental Economics Centre and founder of Bokartisz (personal communication, 9 August 2007, Budapest): "after we founded Bokartisz, we began to elaborate a land-use and flood protection plan for the Bodrogköz. By the end of 2002, start of 2003, the concept was put together. The engine, of course, was Géza Molnár."

What is significant here is that the idea to promote floodplain rehabilitation came from a bottom-up process based on two decades of practical local experience. It was negotiated with local municipalities in cooperation with a small interdisciplinary group of researchers. These actors combined elements of the traditional water steering system with floodplain rehabilitation and rural development. Thus, the new idea was developed in response to local problems independent of the national policy process and the problems recognized by the national administration.

The Bokartisz founders' knowledge of the local situation and of floodplain rehabilitation is impressive. We had to analyze, however, how widely this explanation of the origin of the new idea and its development was supported. A series of interviews and a public survey carried out between 2000 and 2001 in the Tisza region reveal that opinions on flood protection differ. Opinions range from increasing the height of the whole levee system, a measure supported by most water authority experts, to pursuing alternative solutions like partial rehabilitation of the floodplains and removal of levees to create natural reservoirs, ideas supported by most local mayors and NGOs (Vári et al. 2003). In our interviews in 2007 and 2008, mayors who are members of Bokartisz and farmers who collaborate with Bokartisz share the opinion that Bokartisz originated the alternative solutions. The planning agency VÁTI, also names Bokartisz as the originator. Other stakeholders, however, hold the alternative notion that new solutions emerged from the debates among different actors and cannot be attributed to a single player. The water board director for the larger Bodrogköz area recalls (personal communication, 22 August 2007, Sárospatak):

I have no clear memory when new ideas
were introduced. It was more a vision and
an evolutionary process. Many people were
asking. 'If there is an option to keep the
water, what extra benefits could this
provide?'It was quite obvious not to use the
reservoir only once every 30 years, when
there is a high flood. [... I this area has low
agricultural value. Nature restoration was
mentioned as a potential income source.
For example, in 2002 the environmentally
sensitive zones were launched and gave a
push to this thinking. Later, the agro-
environmental payments were introduced.
And we are still waiting for other financial
opportunities that will be attached to the
reservoir-polder scheme.

The administrative agencies bring another perspective on the origin of new ideas incorporated into the water policy. The then-ministerial head of department responsible for the new water policy (Department of Water Damage Prevention at the Ministry of Transport, Communication and Water) does not recall that floodplain revitalization and a rural development program were new elements in the water policy that the counties in the region had to request. Instead, he argues that the first version of the new water policy already allowed for these elements as the main innovation, the retention reservoirs, was already foreseen (personal communication, 30 October 2006, Budapest). In addition, the national government knew that, as an accession country to the European Union (EU), it would soon have to comply with European Directives like the Water Framework Directive (Commission of the European Communities 2000a) and was keen to make use of European funds. Civil servants were aware that ideas in line with integrated water management and rural development were more likely to comply with requirements attached to European support than classic flood protection. Representatives from various ministries had participated in European consultations and study tours where the prospects of regional support were presented. The head of the Hungarian office of the World Wide Fund for Nature (WWF) had experience working on the WWF Living Rivers Project and brought this experience to his position 
as a member of the body charged with preparation of the new water policy in 2000 (Zöckler et al. 2000). However, notwithstanding these international influences, integral and participatory planning were relatively new in Hungarian water management. Many people at the water and planning authority had been trained as civil engineers and strongly believed in river normalization. Under the socialist regime, the water authority had always been a strong hierarchical organization with significant financial resources (Fejér 2004).

In the international context, the degree to which introducing floodplain rehabilitation was new is debatable. The concept of river rehabilitation did not originate from Hungary. Hungarian scientists and government officials may have taken inspiration from other countries. For example, in 2000, Hungarian scientists participated in the Conference on River Restoration in Europe that concluded with the following statement: "River restoration is internationally popular. Many river restoration projects are being implemented. River restoration will even get higher attention within the framework of the implementation of the European Water Framework Directive" (Fokkens 2001). Many countries were considering non-structural or "soft" measures from a sustainability perspective (Kundzewicz 2002, Meijerink 2005). Were there signs of investigation of river restoration and rehabilitation in the Hungarian scientific community? In the seventies, a small number of scientists in the region had studied the traditional water management system. Publications focused on the operation of the traditional system without making a link to present-day water management (Andrásfalvy 1973). In the eighties and nineties, scientists in Budapest engaged in similar studies (Lászlóffy 1982). Karácsonyi (2001) published one of the first papers in English covering the topic. Building on the Association for Local and Regional Development's study (1997), his paper highlighted the benefits of reintroducing the traditional system and floodplain rehabilitation, but did not reference a new water policy. More recently, national and international researchers started to publish on the traditional water management system to cope with present flood risks (e.g., Vári 2001, LinneroothBayer and Vári 2003, Sendzimir et al. 2004).

In summary, we identified two main sources of the new ideas regarding water policy in the Tisza. Those individuals involved with the Bokartisz coalition insist that their group developed the new ideas independently of the government. Members of Bokartisz - and especially its leader - combined elements from historical analysis, theory, and field experiments. In this view, the origin of the new ideas is mostly local. On the other hand, people within the administration point out that some elements were already present in the first version of the water policy and that the new ideas evolved from the interactions during the development of the plan. What emerges from these separate points of view is that the recognition by "both sides" of the ideas as their own, or at least as ideas that were not foreign, may have been instrumental in their incorporation into the water policy in 2003.

\section{Build coalitions to sell ideas}

This section explores the strategy of individuals to build coalitions for selling new ideas. Using the definition set forth by Huitema and Meijerink (2009), we define coalitions as groups of actors from more than one organization with shared beliefs and explicit agreements on how to use resources to achieve common goals. Various regional and national NGOs emerged in Hungary in the 1980s that focused on rural development and nature conservation. In the Tisza region, a series of independent, locally driven initiatives began in the 1990s and each aimed to improve the economic and ecological situation at the local level (Government of Hungary and UNDP - GEF 2004). Typically, these initiatives involved local government, local representatives, NGOs, private companies, and scientists from a micro-region and covered one to several thousand hectares. To capitalize on local experience and to strengthen cooperation, Bokartisz was established in 2001 as a non-profit organization. Its legal status allowed Bokartisz to attract funding and become the program office for a landscape rehabilitation program that produced a set of concepts that were discussed and endorsed by all its members. Beyond concept development, coalition members contributed in various ways. The participating municipalities gave moral support and support in kind (for example, by offering office facilities). Scientific and technical support came from researchers at national institutes. Together with Bokartisz members, these researchers assessed whether Bokartisz' concepts could lead to sustainable regional benefits.

We propose that linking traditional local water management with contemporary notions of nature 
conservation and rural development prepared the ground for the new coalition to be formed. For the purpose of this paper, we focus on Bokartisz as a case of a coalition aiming at water policy change.

We start by analyzing the relationship between Bokartisz and the development of the VTT. In the autumn of 2001, Bokartisz hosted a meeting in the region where the responsible ministry also presented its first version of the water policy. According to the leader of Bokartisz (personal communication, 22 August 2007, Bodrogköz), "We had our concept ready and wanted to present it at this meeting." This summarizes the belief of the founders of Bokartisz that the new ideas were developed first, independently of the new water policy. Only when the government made its initial presentation did Bokartisz members realize that it went against the new concept they had developed. In 2002, they started to formulate their critique against the VTT. According to a founder of Bokartisz from the Hungarian Environmental Economics Centre (personal communication, 9 August 2007, Budapest):

It was a great shock to see the VTT in that form with the 13 reservoirs [...] it was against our concept as Géza analyzed it. The good thing for our concept was that the plan could not be done between two dikes, and water had to be channeled into reservoirs. The bad thing was that the core of the plan was against the holistic floodplain concept because its only aim was to decrease the flood level between the dikes. There was not much attention to what happens in and between the reservoirs.

Bokartisz held the prevailing water management approach responsible for many problems in the Tisza region. This opinion was supported by scientists who had concluded that the flood defense system had reached its limits, and dike construction alone could not accommodate higher flood levels (Timár and Rácz 2002). A central person at the Hungarian Environmental Economics Centre and Bokartisz founder recalls (personal communication, 9 August 2007, Budapest):

In the beginning of 2003, we issued a statement that the VTT in this form cannot be accepted as it conflicts with rational land-use. As NGOs do, we issued it to the press and raised our voice at all venues. As a result, the Ministry [Ministry of Transport, Communication and Water, represented by the responsible Head of Department and his Deputy] said: 'Let the civic organizations and NGO stell what they would like.' [...] A meeting was organized in Budapest where Géza [Molnár] and Tamas Cseloszki presented the concept for the Bodrogköz and the whole Tisza. [...] This point of view was channeled into the VTT, it seemed. For me, my impression is that the high level leaders responsible for water management understood that we did not only like to shout, but that we had a concept and could work it out if given the opportunity.

In February 2003, the Hungarian government endorsed the decree that included rehabilitation of the primary floodplain and rural development as objectives for the new water policy along with flood protection. These objectives were still far from the main innovation that Bokartisz was calling for: to channel water into the landscape and to connect water bodies. However, Bokartisz became one of the partners in developing the implementation plan and its leaders were thus given the opportunity to "sell" their concept.

These series of events suggest that Bokartisz members managed to convince other parties to consider their new concept. The question is then raised when they felt their ideas were taken seriously and the degree to which they were deliberately strategic in their efforts towards this result. As recalled by a founder of Bokartisz from the Hungarian Environmental Economics Centre (personal communication, 9 August 2007, Budapest):

The moment was maybe the first negotiations in spring 2003 and then when it became part of the planning in summer 2003. The proof was when we saw our work as an attachment to the government decree. We [the founders of Bokartisz] said then: 'It's real' [...] It came as a surprise. As an expert and NGO you get accustomed that you write papers, you send them in, you give your own statement, and nothing happens. Sometimes when it happens, when you open the revised plan and you find your own proposal there, it is a big surprise. 
This account suggests that founding the Bokartisz coalition was important in uniting the voice of various organizations in the region that had not previously been heard. The Bokartisz founders developed their concept in time for it to be considered in the new water policy, although they had not timed for this. Instead, the coalition joined the opposition as soon as it considered the new water policy at odds with its own concept. Representing the larger Bokartisz coalition, a small group of two to three people communicated with the central administration. They presented decision makers at the Ministry of Environment and Water with their critique together with their new ideas. Is this account of events enough to explain the transition in water policy? And why did the transition occur at that particular moment in time? Who allowed Bokartisz to become a partner at the negotiation table? We consider these questions in the next section by reviewing the transition in water policy and key actors from the perspective of "windows of opportunity."

\section{Create and use windows of opportunity}

This section assesses whether a window of opportunity was created, recognized or used to launch new ideas. First we describe the three streams that must couple for such windows to be exploited successfully: the problem stream (issue on the public agenda); the political stream (issue on the political agenda); and the policy stream (attention to policy options related to the issue) (Kingdon 1995).

Looking at the problem stream, events began in 1998 with the first major flood in the Tisza for twenty years. The floods that followed annually each produced a new record water level in at least one section of the river (Timár and Rácz 2002). In 2000, the eyes of the world were on the Tisza when, in January, a cyanide spill at a gold mine in nearby Romania wiped out aquatic life and led to several tons of dead fish being pulled from the Tisza. Then, in March, floodwaters rose to a 100-year high. Summer followed with a record-breaking heat wave. Another disaster occurred in 2001 when embankments broke at two places and the Bereg region was flooded, seriously damaging two thousand houses. In Figure 3, we illustrate the problem stream by looking at the Tisza news coverage. We approximate news coverage by the number of occurrences per month of the words
"Tisza" together with "water" in Google News between 1998 and 2007 (line in Figure 3). News coverage shows clear peaks around the time of the floods in November 1998, March 1999, and 2001. The Tisza River received the most attention in international news around the flood and cyanide spill in 2000 and the floods in 2001 and 2006.

Figure 3 also illustrates the political stream by tracking the attention paid to the Tisza on websites of the coalition government parties. The figure shows the normalized total number of hits per year for Google searches of the coalition parties' websites. The 2001 flood happened during the election campaigns and attracted sizeable political attention. Judging by website coverage of the topic, political parties' interest in the Tisza also spiked in 2006. This attention coincided with the 2006 elections and another major flood. A second illustration of the political stream in Figure 3 is the level of attention paid to the Tisza by the Hungarian parliament. We approximated this attention by reviewing the number of occurrences of the word "Tisza" per year on the parliament website (http:// www.mkogy.hu). Figure 3 shows how the Tisza gained importance on the parliamentarian agenda in 2000 and peaked in 2004 when parliament approved the "Tisza Law". The figure also shows that attention has waned and that the Tisza has not attracted the same level of parliamentary attention since 2004.

A combined account of the problem, political, and policy streams suggest that the 1998,2000, and 2001 flood events sparked a sense of urgency at the political level to develop a new water policy for the Tisza. In June 2002, a new coalition of socialists and free democrats replaced the conservative, center-right government. The coalition members wanted to put their mark on the ongoing policy process that they had inherited. From this perspective, the autumn of 2002 provided an excellent opportunity for the introduction of new ideas. For the window of opportunity to open, the high visibility of the problem stream, the negative attention for existing policy options and the changing institutional context may have been crucial. As discussed in previous sections of this paper, the Bokartisz coalition had by this time published its ideas and started to actively oppose the existing version of the VTT plan. Support for the existing policy options was waning. Municipalities and the Hortobágy National Park authority had rejected the location of a reservoir in 
Fig. 3. Windows of opportunity illustrated by the normalized number of occurrences of specified terms arising from online search using Google. Note: The incorporation of Internet-based figures comes with the recognition that the medium has become increasingly used by political parties and that the number of issues covered on their websites and the number of pages itself have increased. Thus the figure should be read only as an indication of the changing attention of party websites to the Tisza and not as an absolute assessment of the political agenda of the parties.

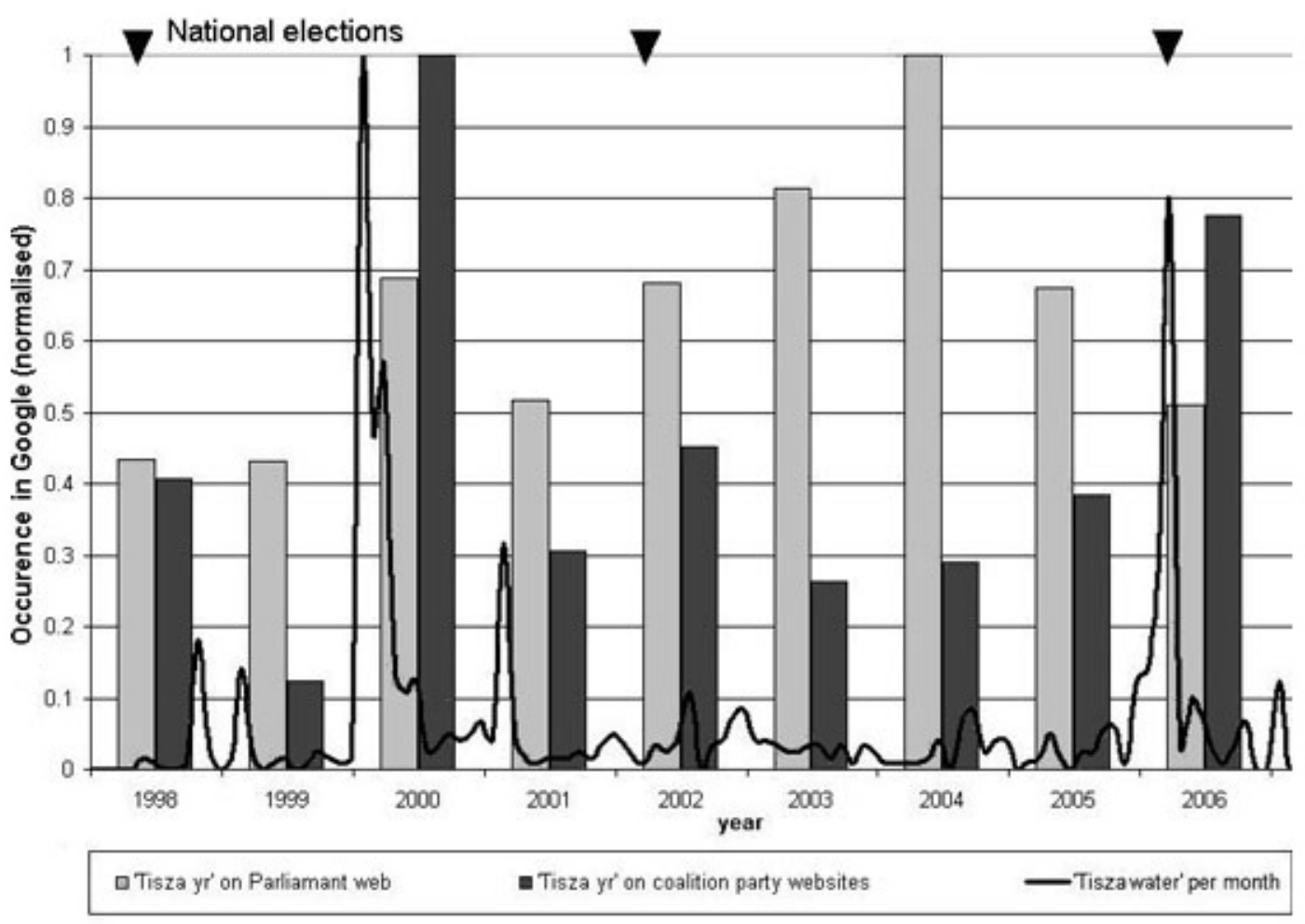

their territory. The need for local support was becoming increasingly clear within the administration. At the same time, the Government had to reduce its budget deficit as a condition for EU membership, making it imperative to find new sources of financing (Vári et al. 2003). European legislation, directives, and funding mechanisms, like the new agro-environmental support schemes of the European Common Agricultural Policy, favored integrated policies and management approaches. In addition, the EU promoted participation of civil society for a democratic system of government (Commission of the European Communities 2000b, 2001). The combination of these factors opened a window for incorporating new ideas in water policy development.
Did Bokartisz members actually time their interventions and local experiments to be ready for cooperation at the end of 2002 and use this window of opportunity? Accounts of its founders suggest that essentially they developed their ideas independently from the political stream. In contrast, in our interview, the ministerial head of department who was at the time responsible for the water policy expresses a conscious and purposeful consideration of high-profile problems, national politics, and policy options. He recollects using the sense of urgency after recurring floods to first secure financial support for a new flood protection program and then turn it into a national program (personal communication, 30 October 2006, Budapest). He 
recalls his distress when, after the 2002 national elections, the water authorities were merged with the environmental authorities and their staff and budget reduced. This situation created a need to build new cooperation to ensure successful use of the window of opportunity. He became Deputy State Secretary for Water at the new Ministry for Environment and Water. He suggests that an interministerial committee was installed at his instigation to develop the water policy further. This committee both changed the role of the administration and added a new venue for the transition process. We investigate the role of the new venues in the next section.

\section{Play multiple venues}

The previous sections have looked at the origin of the new ideas, the coalitions that were built to sell them, and the opportunities for introducing new ideas into the water policy at a particular moment in time. Here, we ask whether individuals or groups of individuals sought out alternative venues to promote new ideas. We understand venues as the possible places where policy issues can be debated, including various levels of government, the forums of scientists and legislatures, and the media (Baumgartner and Jones 2002). We focus on the choice of venue of the actors identified in previous sections: the national government (particularly the ministry responsible for water policy), the local government (including the mayors and water boards), and the Bokartisz coalition.

By 2000, the EU had become a key new venue for debating policy requirements and funding opportunities (Veres 2004). Politicians and civil servants from the accession countries were actively briefed on European funding possibilities, such as structural funds, cohesion funds, and agricultural subsidies. They were invited to participate in multinational projects and conferences in the EU. Although Europe was not a venue where civil servants deliberately lobbied for the new water policy, they recognized the restrictions and opportunities in the European regulations and financing conditions. Whereas national funding previously had supported engineering solutions, the European financing conditions offered opportunities for the new idea of river rehabilitation. Government Decree 1022/2003 on the improvement of the Vásárhelyi water policy specifies that "financial resources should be determined with respect to the
European Union's common joint financing conditions".

To prepare the implementation plan for the water policy, the national government, at the instigation of the Ministry of Environment and Water, created two key new venues. First, it established the interministerial committee that represented a larger group of ministries than in the planning stage. The committee was co-chaired by the Deputy State Secretary for Water, who had been previously responsible for the water policy, and a representative of the Ministry of Agriculture and Rural Development. The committee intensively consulted research institutions, national park authorities, local government, and civic groups (Váradi 2003). The second venue consisted of five open public procurement tenders to support the drafting of the new water policy. VÁTI, the national planning agency for regional development, and VIZITERV, the water resources design bureau, coordinated the tenders. Established through Government Decree 1022/2003, the tenders allowed for increased stakeholder involvement and the representation of local interests in the planning process.

The Bokartisz members used additional venues to express their ideas or undermine the existing water management paradigm. As a coalition with members from municipalities, NGOs, and the scientific community, Bokartisz had in-house experience in playing different venues. Bokartisz issued protests and statements in the press written by its environmental NGO members. The rural development NGOs and municipalities brought experience with training and information dissemination. Farmers, in particular, were approached to participate in pilot projects or public hearings and training sessions. Just like the national government, Bokartisz members looked for new financial instruments; for example, the agroenvironmental support schemes and small pilot projects that farmers could apply for.

In summary, government official and coalition members used a number of new venues to sell and develop the new ideas. The national government supported the transition in water policy by creating two new venues: the inter-ministerial committee and a participatory planning process supported by open public procurement tenders. The EU offered new financial instruments and called for more participatory policy making. Together with the 
national government's focus on European cofinancing, this influenced the prioritization of policy options. The NGO members in the Bokartisz coalition used a range of venues to discredit existing policy options and to lobby locals to support Bokartisz's ideas.

\section{Orchestrate and manage networks}

Turning to the last of the five strategies, we ask how actors cooperated, what networks played a role in the transition in water policy and whether (groups of) individuals actively influenced the operation of networks. In particular, we analyze whether individuals influenced the breakthrough in the development of water policy for the Tisza by breaking up or providing alternative policy networks.

Such an analysis requires determining what networks shaped water management before and during the transition in water policy. In the 150 years before the transition, engineering solutions dominated water management. The water authority was very powerful, especially under the communist regime. Engineers were partly trained in the Soviet Union (Fejér 2004). A strong, informal network of water authorities and contractors developed during this period, and many of these individuals still remain in key positions today. This network entails cooperation over several decades, but without the collective organization and explicit agreement on spending shared resources that are fundamental to an advocacy coalition such as Bokartisz.

Similarly, the environmental NGOs in Hungary form a strong network in which many individuals in key positions know each other from the communist environmental youth movement. In 2000, the environmentalists were becoming increasingly organized. They stressed that continuing levee construction and the resulting narrowing of the riverbed increased flood risks in Hungary. At the same time, researchers at the Water Resources Research Center VITUKI started to study the merits of water retention (Szlávik 2001a, Szlávik 2001b).

At the regional level, the founders of Bokartisz built on the existing networks of key players in the region. The long-running collaboration (or animosity) between the mayors and other central regional actors extends well beyond Bokartisz both in time and number of actors. Networks were built by people who held central positions in state enterprises (for example, the agricultural cooperatives) and in the administration under the communist regime. In the turbulent times after 1989, well-informed landowners could profit from land consolidation. The consolidation of land around the Cigánd reservoir illustrates the importance of regional players. In our interviews it was suggested that some mayors and large landowners speculated on the location of the reservoir and acquired land shortly before the site was selected. These individuals could benefit from expropriation or from the compensation and the agro-environmental support schemes proposed in association with the reservoir. Such benefits seem to have been more important to these players than any particular water policy. In this manner, they did not manage the transition in water policy but were important in influencing site selection and sitespecific implementation. According to a civil servant from the Ministry of Agriculture and Rural Development (personal communication, 25 October 2006, Hortobágy):

Local mayors - who might also be members
of Parliament - are among the most
powerful actors. They have a voice in
Ministries, since an important part of
ministerial routine is to give an adequate
response to initiatives coming from the local
administrations; moreover, local mayors
have strong capacity to influence the
process of practical implementation of the
plans and projects.

The research community also deserves notice as a network of actors involved in the transition. Bokartisz members - especially Géza Molnár report that they took inspiration from scientists to conduct the 1980s experiments in river revitalization. Studies of the traditional management of water and land-use were of particular importance (e.g., Andrásfalvy 1973, Bellon 1991). Following the cyanide spill in 2000, an increasing number of international research projects offered opportunities to discuss, test, and promote floodplain management and river rehabilitation. Individuals from the research community extended their networks through international research and development projects. In 2002, the state-owned Water Resources Research Center (VITUKI) won the European commission-funded Tisza River Project on sustainable use of water resources and 
ecological values in the Tisza River Basin (http:// www.tiszariver.com). In 2004, individuals from the research community together with Bokartisz and other local organizations secured a substantial UNDP/GEF project for protecting biodiversity in the Tisza Basin (http://www.elotisza.hu) and INTERREG III project funding. The NGO members in the Bokartisz coalition sought national credibility by entering domestic and international research networks. The accreditation of VITUKI gave water management schemes crucial national support and legitimacy. As the leader of Bokartisz (personal communication, 22 August 2007, Bodrogköz) explains, "that VITUKI in 2002 was willing to test and support the idea by [hydrological] modeling to see whether the concept works gave a big push because it provided the proposed water steering and shallow flooding with a more scientific foundation."

We cannot currently say to what extent the emergence of international cooperation through research projects won new supporters for the concept of floodplain rehabilitation. We do know, however, that these projects sustained a dialogue between Hungarians across the region about floodplain rehabilitation and rural development. In addition, we know that the national government was intent on finding new sources of funding, and the projects set out above reveal that the new idea of floodplain rehabilitation attracted more international support than engineering-dominated solutions. Members of Bokartisz, especially the researchers, recognized this opportunity and used it to attract funding for promoting floodplain rehabilitation. This cooperation broke up the network of engineers that had designed most of the recent Hungarian water infrastructure and initiated a more interdisciplinary network of researchers. Facilitated by VÁTI, the tenders following the 2003 government decree allowed this network to test the new ideas. The VÁTI team leader responsible for the water policy development process recognizes the importance of strong regional cooperation and representation of local interests (personal communication, 30 October 2006, Budapest):

Another important element in this whole period is how local interests are incorporated. It is very difficult to request from them [local population] because these areas are [socio-economically] the least developed [..]. They also have low lobbying power. The reason why Bokartisz has such a key role in the whole process is that, immediately from the beginning, they were articulating their ideas as a local stakeholder and had the scientific basis and support for them. In addition, they were accepted by the locals. We [VÁTI] are coming from Budapest, and it would take us a long time to be accepted by the local people and to be part of negotiations. So throughout the work we did, we tried really to rely on Bokartisz and involve them in the whole process. They have this kind of special knowledge about the local situation that we from Budapest would never have. If there were more of this high-quality organized local representation, then the whole VTT would be much farther ahead.

To summarize, we found strong existing networks at both the national and the regional level. New interactions between these networks occurred around the time of the transition in water policy. The VÁTI team leader became a major actor due to her facilitation of discussions between the national government, scientists, and local representatives. The VÁTI team admitted Bokartisz as a counterpart and representative of regional organizations throughout the planning process. VÁTI's facilitation of the planning process and its administration of the tenders for the Ministry of Environment and Water cracked the network of the water authority and its engineers and contractors.

\section{DISCUSSION}

What can we learn from the Tisza case about transitions in water policy? The recurring major floods and the cyanide spill on the Tisza River in 2000 were obviously significant, but in what way? The floods and resulting damage were severe, but these two factors were probably not sufficient in themselves to trigger a transition in water policy. They did, however, highlight the problem stream and support regional NGOs' strategy of defining the prevailing water management as unsustainable and demanding a different approach. Thus, the events proved instrumental in broadening the debate about an alternative water policy. Flood retention and integrated river basin management already had supporters in the national government, the academic world, and major NGOs like WWF. This support existed, in part, because European directives advocated these approaches and offered indispensable financial support for them. Application of these 
approaches required also local support and experience. The new Bokartisz coalition of municipalities in the Tisza region, NGOs, and researchers offered both. The founders of Bokartisz had just developed their concept of floodplain rehabilitation and shallow flooding for the Tisza region and had contextualized it for specific locations. In the Bodrogköz area in particular, support from the water board and mayors inside and outside the Bokartisz coalition was high and opposition minimal.

The 2002 national elections brought a new coalition to power. Water affairs were transferred to a new Ministry of Environment and Water, and this situation set the scene for the transition to consolidate in new procedures. The then-upcoming accession to the European Union favored a shift towards participatory and integral planning. In this manner, a window of opportunity for coupling the new ideas, political will and a relevant problem opened in 2002 (cf. Kingdon 1995). A key player to open and use this window was the Head of Department assigned with the development of the policy at the Ministry of Transport, Communication and Water (after the 2002 reorganization, the Ministry of Environment and Water). A government decree was passed in February 2003 that acknowledged floodplain rehabilitation and rural development and that created two new venues for preparing the water policy's implementation plan: an inter-ministerial committee and a series of tendered studies. VÁTI used the tenders to support a new network of researchers, NGOs, and local representatives in creating the spatial plan for the water policy. The national government endorsed the implementation with the October 2003 government decree and the 2004 Tisza law. Endorsement notwithstanding, since 2004 only two of the first six retention areas have been built and the related floodplain rehabilitation and rural development has either not been attained or attained only after many delays.

This paper uses the framework of Huitema and Meijerink (2009; 2010) who postulate that a transition in water policy should become visible in a reorientation of the policy substance or the governance paradigm. Future research may ask what the implications of this work are for deep system transformation where the system is understood and managed in new ways throughout society (cf. van der Brugge et al. 2005, Folke et al. 2005, Olsson et al. 2006, Pahl-Wostl et al. 2009).
Our account of the transition in water policy highlights interactions among key individuals and groups of individuals. It attempts to provide a credible account of the principal actors involved. We do not argue that the result of the interactions was inevitable nor that the policy was "correct", only that the prevailing conditions and interactions made its adoption feasible. The narrative is necessarily compressed and cannot do full justice to the work of the many people who cooperated in the Tisza. However, we hope to have conveyed the main thrust of affairs.

The Tisza case demonstrates the key role of individuals and confirms the use of the strategies identified in the introduction to this issue (Huitema and Meijerink 2010): to develop ideas, to build coalitions to sell ideas, to use windows of opportunity, to play multiple venues, and to orchestrate networks. Closer analysis provides insight into the use of these five strategies. Regarding the development and promotion of ideas, the members in the central coalition who began small-scale experiments deserve extra attention. These experiments built trust and physical proof of cooperation. Here also the interplay of supporters and opponents of policy change is evident. A main challenge for the national government was to get local support. Local farmers, mayors, and the national park authorities had already rejected two possible locations for a retention area. Both Bokartisz members and local mayors outside the Bokartisz coalition were aware of this situation. They offered an area close to the town of Cigánd in the Bodrogköz region to the preparatory body for the new water policy as an alternative location for a retention polder. In the words of the leader of Bokartisz (personal communication, 22 August 2007, Bodrogköz), "Another key element in the success was that we could find a territory that we could offer. There was a territory always affected by inland water stagnation without high nature value: Cigánd." The leader of Bokartisz reported that he was aware of this opportunity before the more detailed planning process started in 2003. It remained less clear when and how the local mayors began to support Cigánd as a location for a VTT retention area. In general, they were keen to highlight secondary benefits they ensured for their municipality by participating in the planning process. These benefits ranged from national funding for a municipal sewerage system to city status for Cigánd, extending the legal status, financial resources, and status in parliament of the 
local government representatives. The management of interests and (financial) resources, either to facilitate or slow the transition in water policy, emerged as a strategy. A witness of the changes in the Bodrogköz stated that (personal communication, 23 October 2007, Bodrogköz) "[t]hose opposing the plan thought it would never pass parliament. When it did, they were shocked. The easiest and most efficient way to block it is though the budget." Related to interest management were strategies that sidestepped good governance principles such as transparency and accountability. These strategies of individuals deserve more attention in future research.

A further observation with respect to the analyzed strategies is the divergent framing of new policy ideas. Whereas civil servants and their technical experts described the new policy ideas as an effective response to new challenges in water management, coalition members stressed that the new ideas had roots in history and tradition and opposed prevailing water management.

With respect to managing networks in the region, legacy effects were strong, with prior social networks and the historic legitimacy of actors determining the nature of the game. Policy analysts should be careful not to overlook the activities of the private sector and consequently omit a potentially important actor and partner. Whereas the origin, advocacy, and management related to the new policy ideas in the Tisza did not lie with bigger private agents, their cooperation became crucial in implementing the new ideas for two important reasons. First, interventions in the floodplain required the cooperation of landowners. Second, implementation of water policy in Hungary could no longer rely solely on national government support. New partnerships had to be built. The new water policy required the cooperation of many partners. It called for an in-depth examination of multi-stakeholder organizations and institutions that were not well understood at the time of the transition in water policy and that represented an emerging and complex factor in many countries around the world.

Finally, it is important to consider to what extent the explored strategies are complementary. Theoretically, looking for 'windows of opportunity' is more oriented towards finding the right time to present ideas, whereas 'venue shopping' is more about finding or creating the right place. In practice in the Tisza case, however, these strategies were found to overlap, as individuals aimed to find the right place at the right time to promote ideas or oppose change.

\section{CONCLUSIONS}

This paper focused on individuals and the strategies they used to facilitate a transition in water policy in Tisza. With regard to the two elements of a transition in water policy - change seen in policy substance or in governance arrangements - the Tisza case exhibits little formal organizational change sustained beyond plan development. In fact, actors identified coordination and clarity of the organizational structure as components that have been sorely lacking in the implementation phase (Werners et al. 2009). This is one of the challenges that actors in the Tisza presently face as the implementation of the policy has been slow and could still fail. Close analysis of the role of individuals during implementation may uncover strategies complementary to those we discussed. In addition, an analysis based on stakeholder interest could be a valuable addition to the idea-centered approach taken in this paper.

We explored five potential strategies of individuals: developing new ideas, building coalitions to sell ideas, using windows of opportunity, playing multiple venues, and orchestrating networks. We conclude that these strategies and the focus on individuals offer a simple and edifying frame for exploring a transition in water policy. Assessing the transition from the perspective of individuals and their strategies yields a number of new insights about a turbulent time, with each strategy pointing at different key actors and events. Important lessons include that the founders of a new coalition linked different objectives to their new ideas. Furthermore, while this coalition elaborated its ideas at the regional level, national policymakers recognized a window of opportunity to link regional support to the policy change being advocated and supported financially at the international level. Development of the policy saw new venues and networks arise that proved influential during the transition. Beyond the importance of developing and debating new ideas, the Tisza case shows that it takes individuals to initiate a transition and people that can take new ideas through a period of confrontation, change, and reorganization. 
Responses to this article can be read online at: http://www.ecologyandsociety.org/vol15/iss2/art24/ responses/

\section{Acknowledgments:}

The authors thank Edward Elgar Publishing who have kindly given permission for the use of material from Huitema, D. and S. Meijerink (eds), Water Policy Entrepreneurs: A Research Companion to Water Transitions around the Globe, Cheltenham, UK: Edward Elgar Publishing, 2009. Work on this paper has been supported by a grant from the European Commission through the European research project ADAM (Adaptation and Mitigation Strategies: Supporting European climate policy, Contract No 018476-GOCE, http://www.adamproject. eu), NeWater (New approaches to adaptive water management under uncertainty, Contract No 511179-GOCE, http://www.newater.info) and from the Dutch Ministry of Agriculture, Nature Conservation and Food Quality. We thank all interviewees and participants of the Tisza regional workshops for sharing their experience. We are gratefulfor the valuable comments and suggestions of research partners, especially Joel Aberbach, Péter Balogh, Tom Christensen, Maria Gordon, Zsolt Harnos, Dave Huitema, Istvan Láng, Louis Lebel, Rik Leemans, Sander Meijerink, Géza Molnár, Jan Sendzimir and the reviewers.

\section{LITERATURE CITED}

Association for Local and Regional Development (ALRD). 1997. Study on the rehabilitation of the 'notch'-system (title translated from Hungarian). Association for Local and Regional Development (ALRD), Debrecen, Hungary.

Andrásfalvy, B. 1973. Ancient floodplain and water management at Sarkoz and the surrounding area before the river regulations (title translated from Hungarian). Vízügyi történeti füzetek $\mathbf{6}$.

Balogh, P. 2002. Basics and Method of Floodplain Management on Middle-Tisza Valley. VATI Kht, Budapest, Hungary.

Baumgartner, F. R., and B. D. Jones, editors. 2002. Policy Dynamics. University of Chicago
Press, Chicago, Illinois, USA.

Bellon, T. 1991. Floodplain husbandry along the Tisza in the XVIII-XIX. century (title translated from Hungarian). Pages 109-124 in Great Plain Research Institute, editor. Alföldi társadalom, volume II. Centre for Regional Studies, Hungarian Academy of Sciences, Békéscsaba, Hungary.

Bellon, T. 2004. Living together with nature. Farming on the river flats in the valley of the Tisza. Acta Ethnographica Hungarica 49(3):243-256.

Botos, C., P. Kajner, G. Molnár, and G. Ungvári. 2002. Floodplain landscape management: concept and concrete steps at the Bodrogköz area. The 'Last Straw' program's ecological historical foundation and the synthesis of the environmental economics analysis (title translated from Hungarian). Bokartisz, Budapest-Karcsa-Nyíregyháza, Hungary.

Caniëls, M. C. J., and H. A. Romijn. 2008. Actor networks in strategic niche management: insights from social network theory. Futures 40(7):613-629.

Commission of the European Communities. 2000a. Directive 2000/60/EC of the European Parliament and of the Council establishing a framework for the community action in the field of water policy (EU Water Framework Directive), The European Parliament and the Council of the European Union, Brussels Belgium.

Commission of the European Communities. 2000b. Discussion paper: the Commission and nongovernmental organisations: building a stronger partnership. Report \#18.1.2000, COM(2000)11 final. Brussels, Belgium.

Commission of the European Communities. 2001. European governance - a white paper. Report \#25.7.2001 COM(2001)428 final. Brussels, Belgium.

Fejér, L. 2004. History of Irrigation, Drainage and Flood Control in Hungary. Pages 331-462 in G. Csekö and L. Hayde, editors. Danube Valley: history of irrigation, drainage and flood control. ICID, New Delhi, India.

Fokkens, B. 2001. Preface. Pages 344 in H. J. Nijland and M. J. R. Cals, editors. Proceedings conference on river restoration in Europe 2000. 
Institute for Inland Water Management and Waste Water Treatment RIZA, Ministry of Transport, Public Works and Water Management, Wageningen, The Netherlands.

Folke, C., T. Hahn, P. Olsson, and J. Norberg. 2005. Adaptive governance of social-ecological systems. Annual Review of Environment and Resources 30(1):441-473.

Government of Hungary, and United Nations Development Programme - Global Environment Facility (UNDP-GEF). 2004. Conservation and restoration of the globally significant biodiversity of the Tisza River floodplain through integrated floodplain management (Tisza-biodiversity project). United Nations Development Programme - Global Environment Facility.

Hajer, M. 1995. The politics of environmental discourse: ecological modernisation and the policy process. Clarendon Press, Oxford, UK.

Huitema, D., and S. Meijerink. 2010. Realizing water transitions: the role of policy entrepreneurs in water policy change. Ecology and Society 15(2): 26. [online] URL: http://www.ecologyandsociety.org/vol15/ iss2/art26.

Huitema, D., and S. Meijerink, editors. 2009. Water policy entrepreneurs: aresearch companion to water transitions around the globe. Edward Elgar Publishing, Camberley, UK, and Northampton, Massachusetts, USA.

Karácsonyi, Z. 2001. Rehabilitation of the 'notch'system as a tool for multipurpose floodplain management on the Upper-Tisza River. Pages 344 in H. J. Nijland and M. J. R. Cals, editors. Proceedings Conference on River Restoration in Europe 2000. Institute for Inland Water Management and Waste Water Treatment (RIZA), Wageningen, The Netherlands.

Kingdon, J. W. 1995. Agendas, alternatives and public policies. Second edition. Harper Collins, New York, New York, USA.

Kundzewicz, Z. W. 2002. Non-structural flood protection and sustainability. Water International 27(1):3-12.

Lászlóffy, W. 1982. Tisza river: construction and water management in the Tisza water regime (title translated from Hungarian). Akadémiai Kiadó, Budapest, Hungary.

Linnerooth-Bayer, J., and A. Vári. 2003. A modelbased stakeholder approach for designing disaster insurance. International Institute for Applied Systems Analysis, Laxenburg, Austria.

Linnerooth-Bayer, J., A. Vári, and M. Thompson. 2006. Floods and fairness and Hungary. Pages 181-204 in M. Verweij and M. Thompson, editors. Clumsy solutions for a complex world: governance, politics and plural perceptions. Palgrave-Macmillian, Houndmills, Basingstroke, UK.

Meijerink, S. 2005. Understanding policy stability and change. the interplay of advocacy coalitions and epistemic communities, windows of opportunity, and Dutch coastal flooding policy 1945-2003. Journal of European Public Policy 12(6):1060-1077.

Olsson, P., L. H. Gunderson, S. R. Carpenter, P. Ryan, L. Lebel, C. Folke, and C. S. Holling. 2006. Shooting the rapids: navigating transitions to adaptive governance of social-ecological systems. Ecology and Society 11(1):18. [online] URL: http:/ /www.ecologyandsociety.org/vol11/iss 1/art18/

Pahl-Wostl, C., J. Sendzimir, and P.Jeffrey. 2009. Resources management in transition. Ecology and Society 14(1):46. [online] URL: http://www.ecolog yandsociety.org/vol14/iss1/art46/

Sabatier, P. A. 1988. An advocacy coalition framework of policy change and the role of policyoriented learning therein. Policy Sciences 21 (2):129-168.

Sendzimir, J., P. Balogh, A. Vári, and T. Lantos. 2004. The Tisza River Basin: slow change leads to sudden crisis. Pages 261-290 in S. Light, editor. The Role of biodiversity conservation in the transition to rural sustainability. ISO Press, Amsterdam, Netherlands.

Szlávik, L. 2001a. Flood protection development in the Tisza Valley (title translated from Hungarian). in Geographical Conference / Földrajzi Konferencia, Szeged, Hungary.

Szlávik, L. 2001b. The water management research and development agenda (title translated from Hungarian). VITUKI Rt., Budapest, Hungary. 
Timár, G., and T. Rácz. 2002. The effects of neotectonic and hydrological processes on the flood hazard of the Tisza region (East Hungary). EGU Stephan Mueller Special Publication Series 3:267-275.

Vámosi, S. 2002. The effect of excess waters on the development of the Great Plain Regions (in Hungarian, summary in English). University of Debrecen, Debrecen, Hungary.

van der Brugge, R., J. Rotmans, and D. Loorbach. 2005. The transition in Dutch water management. Regional Environmental Change 5 (4):164-176.

Váradi, J. 2003. For the blooming of the Tisza Region (title translated from Hungarian). Jászkunság Almanac. [online] URL: http://epa.oszk. hu/00100/00179/00001/pdf/02viragzo.pdf.

Vári,A. 2001. Flood risk management in the Upper Tisza Region: results of stakeholder interviews. IIASA, Laxenburg, Austria.

Vári, A., J. Linnerooth-Bayer, and Z. Ferencz. 2003. Stakeholder views on flood risk management in Hungary's Upper Tisza Basin. Risk Analysis 23 (3):537-627.

Veres, J. 2004. Hungary in an enlarged Europefiscal and financial relations. in EIB Conference: Strategies and frameworks for Hungary's growth and convergence after EU Accession. European Investment Bank, Budapest, Hungary.

VITUKI. 2004. Rebirth of the River Tisza - the new Vásárhelyi Plan. National Environment, Conservation and Water Authority, Water Resources Research Institute (VITUKI), Budapest, Hungary.

Werners, S. E., Z. Flachner, P. Matczak, M. Falaleeva, and R. Leemans. 2009. Exploring earth system governance: a case study of floodplain management along the Tisza River in Hungary. Global Environmental Change 19(4):503-511.

Zöckler, C., E. Wenger, and J. Madgwick. 2000. Assessment of WWF river and floodplain restoration projects in Europe. In Proceedings Conference on River Restoration in Europe, Wageningen, The Netherlands. 